\title{
Pengaruh Kualitas Audit Terhadap Manajemen Laba
}

\author{
Ingrid Christiani ${ }^{1}$; Yeterina Widi Nugrahanti ${ }^{*}$ \\ ${ }_{1}^{1}$ Fakultas Ekonomika dan Bisnis, Universitas Kristen Satya Wacana \\ Jl. Diponegoro 52-60, Salatiga, Jawa Tengah 50711 \\ *Korespondensi penulis, email: yeterina.nugrahanti@staff.uksw.edu
}

\begin{abstract}
ABSTRAK
Tujuan penelitian ini adalah untuk menguji pengaruh kualitas audit terhadap manajemen laba. Kualitas audit pada penelitian ini diukur dengan Kantor Akuntan Publik (KAP) menjadi big four dan non-big four dan spesialisasi industri auditor. Penelitian ini menggunakan empat variabel kontrol, yaitu ukuran perusahaan, leverage, rasio arus kas operasi dan pertumbuhan perusahaan. Data yang digunakan dalam penelitian ini merupakan data sekunder yang berasal dari laporan keuangan perusahaan yang terdaftar di Bursa Efek Indonesia pada tahun 2010-2011. Dengan menggunakan purposive sampling, penelitian ini mendapat 174 sampel perusahaan. Metode analisis data yang digunakan dalam penelitian ini adalah uji regresi linier berganda. Hasil penelitian menunjukkan bahwa ukuran KAP tidak berpengaruh terhadap manajemen laba. Spesialisasi industri auditor berpengaruh negatif terhadap manajemen laba. Dari keempat variabel kontrol yang digunakan dalam penelitian ini, hanya arus kas operasi dan pertumbuhan yang berpengaruh terhadap manajemen laba, sementara kedua variabel lainnya, yaitu ukuran perusahaan dan leverage, tidak berpengaruh.
\end{abstract}

Kata kunci: Kualitas audit, ukuran KAP, spesialisasi industri auditor, manajemen laba.

\begin{abstract}
The purpose of this study is to examine the effect of audit quality on earnings management. The audit quality is proxied by the Public Accounting Firm size- (big-four and non-big four) and auditor's industry specialisation. This study used four control variables, which are firm size, leverage, operating cash flow ratio and growth prospect. This study used secondary data derived from the financial statements of listed companies in Indonesia Stock Exchange in 2010-2011. Based on the method of purposive sampling method and was obtained 174 observations. The technique for examining the hypothesis is multiple regression analysis. The results show that accounting firm size does not significantly influence on the earnings management. Auditor's industry specialisation has a negative effect on the earnings management. Of the four control variables used in this study, only the operating cash flow and growth that effect on earnings management, while the other two variables, namely the firm size and leverage, have no effect.
\end{abstract}

Keywords: Audit quality, public accounting firm size, auditor's industry specialisation, earnings management.

\section{PENDAHULUAN}

Salah satu ukuran kinerja perusahaan yang sering digunakan sebagai dasar pengambilan keputusan adalah laba yang dihasilkan perusahaan, laba tersebut diukur dengan dasar akrual (Subramanyam 1996). Kinerja manajemen perusahaan tercermin pada laba yang terkandung dalam laporan keuangan, sehingga informasi laba merupakan informasi yang penting sebagai dasar pengambilan keputusan investasi. Informasi laba ini sering menjadi target rekayasa tindakan oportunis manajemen untuk memaksimalkan kepentingannya, sehingga dapat merugikan investor. Perilaku mengatur laba perusahaan sesuai dengan keinginan manajemen ini dikenal dengan istilah manajemen laba (earnings management).

Manajemen laba timbul sebagai dampak persoalan keagenan yaitu ketidakselarasan kepentingan antara manajer dan pemilik perusahaan yang dikarenakan adanya asimetri informasi. Asimetri informasi adalah suatu kondisi dimana 
adanya ketidakseimbangan dalam perolehan informasi antara manajemen dan pemegang saham dimana manajemen memiliki informasi yang lebih dibanding dengan pihak eksternal.

Kasus manajemen laba yang pernah terjadi di Indonesia adalah manajemen laba pada PT Kimia Farma Tbk. Pihak manajemen PT. Kimia Farma melakukan penggelembungan (mark up) laba pada laporan keuangan tahunan 2001 sebesar Rp 32,6 milyar. Berdasarkan penyelidikan Bapepam, disebutkan bahwa KAP yang mengaudit laporan keuangan PT Kimia Farma telah mengikuti standar audit yang berlaku, namun gagal mendeteksi kecurangan tersebut. Selain itu, KAP tersebut juga tidak terbukti membantu manajemen melakukan kecurangan tersebut (Kompas, 21 November 2002).

Untuk dapat mengembalikan kepercayaan pihak pemakai laporan keuangan, sangat diharapkan kualitas audit yang baik (Lughiatno, 2010). Namun tidak dapat dipungkiri bahwa laporan keuangan perusahaan akan diaudit oleh auditor yang memiliki kualitas yang berbeda-beda. Ardiati (2005) menyatakan audit yang berkualitas tinggi (high-quality auditing) bertindak sebagai pencegah manajemen laba yang efektif, karena reputasi manajemen akan hancur dan nilai perusahaan akan turun apabila pelaporan yang salah ini terdeteksi dan terungkap. Ratmono (2010) menyatakan bahwa auditor yang berkualitas mampu mendeteksi tindakan manajemen laba yang dilakukan klien. Jasa audit merupakan alat monitoring terhadap kemungkinan timbulnya konflik kepentingan antara pemilik dan manajer serta antara pemegang saham dengan jumlah kepemilikan yang berbeda. Jasa audit dapat mengurangi asimetri informasi antara manajer dan stakeholder perusahaan dengan memperbolehkan pihak luar untuk memeriksa validitas laporan keuangan (Jensen dan Meckling, 1976).

Kualitas audit dapat diukur dengan menggunakan ukuran KAP (KAP The big-4 dan KAP non The big-4) dan spesialisasi industri auditor (Gerayli et al., 2011). Gerayli et al. (2011) menyatakan bahwa ukuran KAP berhubungan negatif dengan manajemen laba yang diukur dengan discretionary accrual. Rusmin (2010) dan Meutia (2004) menyatakan bahwa tindakan manajemen laba terhadap hasil audit yang dilakukan oleh KAP The big-4 lebih rendah daripada KAP non The big-4.

Penelitian yang dilakukan Gramling et al. (2001) menunjukkan bahwa penggunaan spesialisasi industri auditor dapat mengetahui adanya manajemen laba, kesalahan prediksi dan kemampuan untuk memprediksi arus kas mendatang. Hal ini berarti laba perusahaan yang diaudit oleh spesialisasi industri auditor mempunyai daya prediksi arus kas mendatang yang lebih akurat dibandingkan dengan auditor non spesialisasi industri. Becker et al. (1998) menjelaskan bahwa adanya spesialisasi industri auditor dapat mendeteksi manajemen laba karena spesialisasi industri auditor memiliki pengetahuan lebih (superior knowledge) tentang industri tertentu.

Manajemen laba merupakan fenomena dalam bidang akuntansi yang masih sangat penting untuk diteliti pada saat ini, walaupun memang sudah cukup banyak peneliti yang melakukan penelitian mengenai manajemen laba. Peneliti masih tertarik untuk melakukan penelitian mengenai manajemen laba karena berdasarkan hasil penelitian Leuz et al. (2003) menunjukkan bahwa Indonesia berada dalam kluster negara-negara dengan perlindungan investor yang lemah, sehingga terjadinya praktik manajemen laba yang tinggi.

Penelitian ini mengacu pada penelitian Gerayli et al. (2011), tujuan penelitian ini adalah untuk mengevaluasi pengaruh kualitas audit terhadap manajemen laba. Kualitas audit pada penelitian ini dilihat dari ukuran KAP dan spesialisasi industri auditor. Gerayli et al. (2011) menggunakan sampel seluruh perusahaan non keuangan di Iran pada tahun 2004-2009. Hasil dari penelitian tersebut membuktikan bahwa kualitas audit yang diproksikan dengan ukuran KAP dan spesialisasi industri auditor memiliki pengaruh negatif terhadap manajemen laba. Penelitian ini menguji kembali temuan dari Gerayli et al. (2011) pada perusahaan publik di Indonesia dan penelitian ini menggunakan pengklasifikasian spesialisasi industri auditor yang didasarkan pada persentase jumlah perusahaan yang diaudit oleh auditor dalam suatu industri (Andreas 2012).

Hasil dari penelitian ini diharapkan dapat berguna bagi perusahaan terkait dengan pemilihan auditor yang menghasilkan kualitas audit yang tinggi, baik auditor KAP The big- 4 maupun spesialisasi industri auditor. Selain itu, hasil penelitian ini diharapkan dapat bermanfaat bagi investor sebagai tambahan informasi mengenai kondisi suatu perusahaan sehingga mereka dapat berhati-hati sebelum melakukan investasi.

\section{Teori Agensi}

Timbulnya praktik manajemen laba dapat dijelaskan dengan teori agensi yang disebabkan adanya asimetri informasi. Asimetri informasi merupakan suatu kondisi adanya ketidakseimbangan perolehan informasi antara pihak manajemen dan pemegang saham. Manajer memiliki lebih banyak informasi daripada pemegang saham karena 
manajer sebagai pengelola perusahaan. Informasi yang lebih sedikit yang dimiliki oleh pemegang saham dapat memicu manajer menggunakan posisinya dalam perusahaan untuk mengelola laba yang dilaporkan (Zou dan Elder 2004). Kondisi ini menyebabkan munculnya konflik kepentingan antara pemegang saham (prinsipal) dengan manajer (agen), dimana antara agen dan prinsipal ingin memaksimumkan kesejahteraan masing-masing dengan informasi yang dimiliki. Dalam kondisi asimetri seperti ini perlu ada orang ketiga sebagai penengah antara manajer dan pemegang saham yang berperan untuk mengontrol atau sebagai mediator yang mengawasi kinerja agen agar sesuai dengan harapan dan keinginan principal. Auditor merupakan pihak yang dianggap mampu menjembatani kepentingan pihak prinsipal (shareholder) dan pihak manajer (agent) dalam mengelola keuangan perusahaan.

\section{Manajemen Laba}

Sulistyanto (2008) menjelaskan bahwa manajemen laba merupakan upaya manajer perusahaan untuk mempengaruhi informasi dalam laporan keuangan dengan tujuan untuk mengelabui stakeholder yang ingin mengetahui kinerja dan kondisi perusahaan. Manajemen laba merupakan salah satu faktor yang dapat mengurangi kredibilitas laporan keuangan dan menambah bias dalam laporan keuangan, serta dapat mengganggu para pemakai laporan keuangan dalam mempercayai angka-angka dalam laporan keuangan tersebut (Setiawati dan Na'im 2001).

Terdapat motivasi yang mendorong manajer untuk berperilaku oportunis yang sejalan dengan tiga hipotesis utama dalam teori akuntansi positif (Positive Accounting Theory), yaitu bonus plan hypothesis, debt covenant hypothesis dan political cost hypothesis (Watts dan Zimmerman 1990). Dalam bonus plan hypothesis dijelaskan bahwa pemilik perusahaan berjanji manajer akan menerima sejumlah bonus jika kinerja perusahaan mencapai jumlah tertentu. Janji bonus inilah yang merupakan alasan bagi manajer untuk mengelola dan mengatur laba perusahaan pada tingkat tertentu sesuai dengan yang disyaratkan agar dapat menerima bonus. Menurut debt covenant hypothesis, disebutkan bahwa dalam konteks perjanjian hutang, manajer akan mengelola dan mengatur laba perusahaan agar kewajiban hutang perusahaan yang seharusnya diselesaikan pada tahun tertentu dapat ditunda untuk tahun berikutnya. Menurut political cost hypothesis, disebutkan bahwa manajemen laba disebabkan adanya regulasi dari pemerintah, misalnya regulasi dalam penetapan pajak. Besar kecilnya pajak tergantung pada besar kecilnya laba perusahaan. Semakin besar laba perusahaan, maka semakin besar pula pajak yang akan ditarik oleh pemerintah. Kondisi inilah yang merangsang manajer untuk mengelola dan mengatur laba perusahaan agar besarnya pajak yang dibayarkan tidak terlalu tinggi.

Manajemen laba dapat terjadi karena dalam penyusunan laporan keuangan menggunakan basis akrual. Akuntansi berbasis akrual menggunakan prosedur akrual, deferral, pengalokasian yang bertujuan untuk menghubungkan pendapatan, biaya, keuntungan (gains), dan kerugian (losses) untuk menggambarkan kinerja perusahaan selama periode berjalan, meski kas belum diterima dan dikeluarkan (Sulistyanto, 2008). Manajamen laba diproksikan dengan menggunakan discretionary accruals (DAC). Menurut Healy (1985) konsep model akrual memiliki dua komponen, yaitu discretionary accruals dan non discretionary accruals. Discretionary accruals merupakan komponen akrual yang dapat diatur dan direkayasa sesuai dengan kebijakan (discretion) manajerial, sementara non discretionary accruals merupakan komponen akrual yang tidak dapat diatur dan direkayasa sesuai dengan kebijakan manajer perusahaan. Manajer akan melakukan manajemen laba dengan memanipulasi akrualakrual tersebut untuk mencapai tingkat pendapatan yang diinginkan.

\section{Kualitas Audit}

Meutia (2004) mendefinisikan audit sebagai suatu proses untuk mengurangi ketidakselarasan informasi yang terdapat antara manajer dan para pemegang saham dengan menggunakan pihak luar untuk memberikan pengesahan terhadap laporan keuangan. DeAngelo (1981) mendefinisikan kualitas audit sebagai probabilitas gabungan untuk mendeteksi dan melaporkan kesalahan yang material dalam laporan keuangan. Kualitas audit dipandang sebagai kemampuan untuk mempertinggi kualitas pelaporan keuangan perusahaan. Dengan kualitas audit yang tinggi diharapkan mampu meningkatkan kepercayaan investor. Kualitas audit diproksikan dengan dua variabel yaitu ukuran KAP (KAP The big- 4 dan KAP Non The big- 4) dan spesialisasi industri auditor (Gerayli et al. (2011).

\section{Ukuran KAP dan Manajemen Laba}

Timbulnya praktik manajemen laba dapat dijelaskan dengan teori agensi. Di dalam teori agensi mengasumsikan bahwa agen memiliki lebih banyak informasi daripada prinsipal, karena prinsipal tidak dapat mengamati kegiatan yang dilakukan agen secara terus-menerus. Dalam kon- 
disi asimetri seperti ini perlu ada orang ketiga yaitu auditor sebagai pihak yang dianggap mampu menjembatani kepentingan pihak prinsipal (shareholder) dan pihak manajer (agent) dalam mengelola keuangan perusahaan. Ardiati (2005) menyebutkan bahwa audit yang berkualitas tinggi (highquality auditing) bertindak sebagai pencegah manajemen laba yang efektif, karena reputasi manajemen akan hancur dan nilai perusahaan akan turun apabila pelaporan yang salah ini terdeteksi dan terungkap. Kualitas audit dalam penelitian ini diukur dengan ukuran KAP (KAP The big-4 dan KAP Non The big-4) dan spesialisasi industri auditor.

DeAngelo (1981) menyatakan bahwa kualitas audit yang dilakukan oleh akuntan publik dapat dilihat dari ukuran KAP yang melakukan audit. KAP besar (big- 4 accounting firms) dipersepsikan akan melakukan audit dengan lebih berkualitas dibandingkan dengan KAP kecil (non big-4 accounting firm). Hal tersebut karena KAP besar memiliki lebih banyak sumber daya dan lebih banyak klien sehingga mereka tidak tergantung pada satu atau beberapa klien saja, selain itu karena reputasinya yang telah dianggap baik oleh masyarakat menyebabkan mereka akan melakukan audit dengan lebih berhati-hati.

Craswell et al. (1995) menunjukkan bahwa KAP Big- 6 menyediakan lebih banyak sumber daya manusia untuk staff training dan pengembangan keahlian pada bidang industri tertentu dibandingkan KAP non Big-6. Selain itu, KAP Big6 memiliki posisi yang lebih baik untuk melakukan negosiasi dengan klien yang bermaksud mengadopsi praktik-praktik akuntansi agresif dibandingkan KAP non Big-6. Oleh karena itu KAP Big- 6 yang sekarang menjadi KAP Big-4 dapat mengurangi manajemen laba.

Meutia (2004), Sanjaya (2008) dan Herusetya (2009) menemukan bahwa semakin tinggi kualitas audit yang menggunakan ukuran KAP (KAP The Big- 4) maka semakin rendah manajemen laba yang terjadi di perusahaan tersebut. Selain di Indonesia, penelitian Rusmin (2010) di seluruh perusahaan non keuangan di Singapura tahun 2003 dan penelitian Gerayli et al. (2011) di seluruh perusahaan non keuangan di Iran tahun 2004 juga menemukan ukuran KAP berhubungan negatif dengan manajemen laba. Berdasarkan hal tersebut maka dapat dirumuskan hipotesis:

H1: Ukuran KAP berpengaruh negatif terhadap manajemen laba.

\section{Spesialisasi Industri Auditor dan Manajemen Laba}

Gramling et al. (2001) menyatakan bahwa KAP yang memfokuskan pada industri tertentu akan cenderung berinvestasi pada teknologi, fasilitas-fasilitas fisik, pada personil, dan sistem kontrol organisasi yang dapat meningkatkan kualitas audit pada KAP yang terfokus pada industri tersebut. Selain itu, auditor yang memiliki pengalaman dalam industri tertentu akan mampu mendeteksi kesalahan dalam data klien pada industri tersebut daripada auditor yang tidak terfokus pada industri tertentu. Hal ini berarti bahwa spesialisasi industri auditor memiliki kemampuan untuk mendeteksi error dan memiliki pengalaman yang lebih baik daripada non pesialisasi industri auditor. Hal ini ditunjang oleh beberapa hasil penelitian yang menunjukkan bahwa spesialisasi industri auditor, mampu membatasi praktik manajemen laba akrual (Krishnan 2003 dan Balsam et al. 2003). Maletta dan Wright (1996) menjelaskan bahwa auditor yang memiliki pemahaman yang lebih komprehensif tentang suatu tren dan karakteristik industri tertentu akan lebih efektif dalam melakukan audit daripada auditor yang tidak memiliki pengetahuan tentang industri tertentu tersebut.

Secara singkat, spesialisasi industri auditor memiliki pemahaman yang lebih baik tentang karakteristik industri, lebih patuh terhadap standar auditing, memahami resiko dan masalah dalam industri yang diaudit, memiliki kemampuan mendeteksi error lebih baik daripada non spesialisasi industri auditor sehingga spesialisasi industri auditor dapat lebih baik mengurangi manajemen laba akrual daripada non-spesialisasi industri auditor (Januarsi 2009). Penelitian terdahulu yang dilakukan oleh Zhou and Elder (2001), Gerayli et al. (2011) dan penelitian Rusmin (2010) menunjukkan bahwa spesialisasi industri auditor berpengaruh negatif terhadap manajemen laba. Berdasarkan hal tersebut maka hipotesis yang diajukan penelitian adalah:

H2: Spesialisasi industri auditor berpengaruh negatif terhadap manajemen laba.

\section{METODE PENELITIAN}

\section{Populasi dan Sampel}

Populasi dalam penelitian ini adalah perusahaan publik yang terdaftar di Bursa Efek Indonesia pada tahun 2010-2011. Penentuan sampel perusahaan dilakukan dengan metode purposive sampling dengan kriteria sebagai berikut: (1) Perusahaan publik terdaftar di BEI tahun 20102011 yang tidak teregulasi. Klasifikasi industri perusahaan publik yang tidak teregulasi sesuai dengan penelitian (Dunn et al. 2000) dan Mayangsari (2004) yang telah disesuaikan dengan klasifikasi industri pada Bursa Efek Indonesia serta 
kondisi di Indonesia yaitu Basic industry and chemicals, Miscellaneous industry, Property and real estate industry serta Trade, services and investment industry. (2) Sampel industri yang digunakan adalah industri yang minimal memiliki 30 perusahaan, sesuai dengan penelitian Craswell et al. (1995). (3) Perusahaan menerbitkan laporan keuangan yang telah diaudit untuk periode yang berakhir 31 Desember. (4) Data-data mengenai variabel penelitian yang akan diteliti tersedia lengkap dalam laporan keuangan tahunan perusahaan yang diterbitkan pada tahun 2010-2011.

\section{Jenis dan Sumber Data}

Jenis data yang digunakan dalam penelitian ini adalah data sekunder. Data sekunder yang dibutuhkan dalam penelitian ini adalah laporan keuangan perusahaan yang telah diaudit pada tahun 2010-2011 pada perusahaan publik yang terdaftar di Bursa Efek Indonesia. Data sekunder yang dikumpulkan diperoleh dari Pusat Informasi Data Fakultas Ekonomika dan Bisnis Universitas Kristen Satya Wacana, Indonesian Capital Market Directory (ICMD), dan melalui website www.idx. co.id.

\section{Variabel Penelitian}

\section{Variabel Dependen (Variabel Terikat)}

Variabel dependen dalam penelitian ini adalah manajemen laba yang diukur dengan menggunakan model DeAngelo. DeAngelo (1986) berpendapat bahwa total akrual terdiri atas discretionary accruals dan non-discertionary accruals, dimana total akrual tidak mudah terobservasi. Pendekatan ini berasumsi bahwa komponen non-discretionary accruals cenderung stabil sepanjang waktu sehingga yang layak dipertimbangkan adalah komponen discretionary accruals. Sehingga, jika discretionary accruals mempunyai rata-rata sama dengan nol selama periode estimasi maka model ini layak digunakan untuk mengukur discretionary accruals tanpa kesalahan. Perhitungan tingkat akrual yang tidak normal (discretionary accruals) diawali dengan perhitungan total accruals.

1. Total accruals didapat dengan rumus sebagai berikut (Teoh et. al. 1998)

$T A C_{t}=\left(N I_{t}-C F F O\right)$

Dengan:

$\mathrm{TAC}_{\mathrm{t}}=$ Total accruals pada perioda tahun $\mathrm{t}$

$\mathrm{NI}_{\mathrm{t}}=$ Net income pada perioda tahun $\mathrm{t}$

$\mathrm{CFFO}_{\mathrm{t}}=$ Cash flow from operation pada perioda tahun $\mathrm{t}$
2. Perhitungan Nondiscretionary Accruals

DeAngelo (1986) mengasumsikan bahwa total accruals yang nondiscretionary mengikuti pola random walk. Dengan demikian, total accruals yang nondiscretionary (tingkat akrual yang wajar atau normal) pada perioda t diasumsikan sama dengan total accruals yang nondiscretionary pada perioda t- 1 .

$N D A_{t}=T A C_{t-1}$

Dengan:

$\mathrm{NDA}_{\mathrm{t}}=$ Nondiscretionary Accruals pada perioda $\mathrm{t}$

$\mathrm{TAC}_{\mathrm{t}-1}=$ Total accruals pada perioda tahun $\mathrm{t}-1$

3. Setelah menghitung $\mathrm{NDA}_{t}$, maka dapat dihitung besarnya $\mathrm{DA}_{\mathrm{t}}$, dengan rumus:

$\mathrm{DA}_{\mathrm{t}}=\left(\mathrm{TAC}_{\mathrm{t}}-\mathrm{NDA}_{\mathrm{t}}\right) / \mathrm{TA}_{\mathrm{t}}$

Dengan:

$\mathrm{DA}_{\mathrm{t}}=$ Discretionary Accruals pada perioda $\mathrm{t}$

$\mathrm{TAC}_{\mathrm{t}}=$ Total accruals pada perioda tahun $\mathrm{t}$

$\mathrm{NDA}_{t}=$ Nondiscretionary Accruals pada periodat

$\mathrm{TA}_{\mathrm{t}}=$ Total asset pada perioda $\mathrm{t}$

\section{Variabel Independen (Variabel bebas)}

Variabel independen yang digunakan dalam penelitian ini adalah kualitas audit yang diukur dengan ukuran KAP (KAP The big-4 dan KAP non The big-4) dan spesialisasi industri auditor:

1. Ukuran KAP

Pengukuran variabel ukuran KAP menggunakan variabel dummy, nilai 1 jika perusahaan diaudit oleh KAP The big-4, dan 0 jika lainnya (Gerayli et al. 2011).

2. Spesialisasi industri auditor

Dimulai dengan penelitian mula-mula auditor the Big- 8 , auditor dengan spesialisasi industri umumnya didefinisikan sebagai auditor yang melakukan audit lebih dari 10 persen dari pendapatan perusahaan dalam satu industri (Craswell, dkk. 1995). Setelah konsolidasi dari the Big-8 menjadi the Big-6, maka pengukuran spesialisasi menjadi 15 persen sebagai ambang batas (Krishnan 2003) hingga 20 persen (Dunn et al. 2000)

Berdasarkan penelitian sebelumnya, Auditor dikatakan spesialis jika auditor tersebut mengaudit $15 \%$ dari total perusahaan yang ada dalam industri tersebut, sesuai dengan penelitian Craswell et al. (1995). Pengklasifikasian ini didasarkan pada persentase jumlah perusahaan yang diaudit oleh auditor dalam suatu industri (Andreas, 2012). Pengukuran variabel ini menggunakan variabel dummy, nilai 1 jika perusahaan diaudit oleh spesialisasi industri auditor, dan 0 jika lainnya. 


\section{Variabel kontrol}

Variabel kontrol adalah variabel yang dikendalikan atau dibuat konstan sehingga hubungan variabel bebas terhadap variabel terikat tidak dipengaruhi oleh faktor luar yang tidak diteliti (Widhiarso 2011). Variabel kontrol yang digunakan dalam penelitian ini sesuai dengan penelitian Gerayli et al. (2011) yaitu:

1. Ukuran Perusahaan

Ukuran perusahaan dapat menentukan seberapa besar praktik manajemen laba yang dilakukan oleh manajer perusahaan. Perusahaan besar cenderung bertindak hati-hati dalam melakukan pengelolaan perusahaan dan cenderung melakukan pengelolaan laba secara efisien. Zhou dan Elder (2004) menyatakan bahwa perusahaan besar cenderung akan mengurangi tindakan manajemen laba untuk menghindari pengawasan ketat dari analis keuangan dan investor. Variabel ukuran perusahaan diukur dengan menggunakan logaritma natural dari total aset perusahaan (Gerayli et al. 2011)

2. Leverage

Leverage adalah perbandingan antara total utang dan total aset yang menunjukkan beberapa bagian aset yang digunakan untuk menjamin utang. Perusahaan yang memiliki kemungkinan lebih tinggi dalam melanggar perjanjian utang maka perusahaan cenderung melakukan manajeman laba untuk meningkatkan laba perusahaan (Healy dan Palepu 2001). Rumus: LEV $=\underline{\text { Total } u \tan g}$ (Gerayli et al., 2011)

3. Operating Cash Flow ratio

Penelitian Rusmin (2010) mendefinisikan operating cash flow ratio sebagai arus kas dari aktivitas operasi dibagi dengan total aset. Menurut Becker et al. (1998), arus kas dari aktivitas operasi berpengaruh terhadap tindakan manajemen perusahaan dalam mengelola laba.

Rumus: $\mathrm{OCF}=\frac{\text { arus kasdari aktivitas operasi }}{\text { total asset }}$

Gerayli et al. (2011)

4. Growth Prospect

Growth Prospect diukur menggunakan perbandingan antara market value of equity dibagi dengan book value of equity (Gerayli et al, 2011).

Growth Prospect = market value equity/book value equity

Market value equity $=$ Total outstanding share $x$ harga saham

\section{Teknik Analisis}

1. Uji Asumsi Klasik

Dalam penelitian ini digunakan uji asumsi klasik. Pengujian asumsi klasik bertujuan untuk menentukan ketepatan model. Uji asumsi klasik yang akan digunakan dalam penelitian ini meliputi uji normalitas (kolmogorovsmirnov), multikolinearitas (VIF dan tolerance), heterokedastisitas (glejser) dan autokolerasi (run test) (Ghozali 2011).

2. Uji Hipotesis

Uji hipotesis dalam penelitian ini menggunakan analisis regresi berganda (multiple regression). Hipotesis $\mathrm{H} 1$ dan $\mathrm{H} 2$ akan diuji dengan menggunakan model empiris sebagai berikut: $\mathrm{ABSDA}=\alpha+81 \mathrm{BIG}-4+82 \mathrm{SPEC}+B 3 \mathrm{SIZE}+84$ $\mathrm{LEV}+85 \mathrm{OCF}+86 \mathrm{GWTH}+\varepsilon$

Dimana:

$\alpha=$ konstanta

$B=$ koefisien variabel

ABSDA = nilai absolute dari discretionary accruals (manajemen laba). Digunakan nilai absolut karena yang menjadi perhatian dalam penelitian ini adalah besaran dari akrual diskresioner tersebut, bukan arahnya (positif atau negatif) (Balsam et al. 2003).

BIG-4 = ukuran KAP, nilai 1 jika perusahaan diaudit oleh KAP The big-4, dan 0 jika lainnya. SPEC = spesialisasi industri auditor, nilai 1 jika perusahaan diaudit oleh spesialisasi industri auditor, dan 0 jika lainnya.

SIZE = logaritma natural dari total akiva.

$\mathrm{LEV}=$ rasio total hutang atas total aset perusahaan.

OCF = operating cash flow ratio.

GWTH = nilai pasar ekuitas dibagi nilai buku ekuitas.

$\varepsilon=$ residual of error

\section{HASIL ANALISIS DAN PEMBAHASAN}

\section{Sampel Penelitian}

Penelitian ini menggunakan perusahaan publik yang terdaftar di Bursa Efek Indonesia pada tahun 2010-2011. Berdasarkan purposive sampling, didapatkan 174 perusahaan publik yang dijadikan sampel. Dengan jumlah tahun penelitian adalah 2 tahun (2010-2011), maka total data penelitian adalah 348 data. Proses pengambilan sampel dapat dilihat dari Tabel 1.

\section{Statistik Deskriptif}

Statistik deskriptif bertujuan untuk memberikan gambaran atau deskripsi dari suatu data yang dilihat dari jumlah sampel, nilai minimum, nilai maksimum, dan nilai rata-rata (mean) dari masing-masing variabel seperti ukuran perusahaan (SIZE), leverage (LEV), operating cash flow (OCF), pertumbuhan perusahaan (GWTH) dan absolute discretionary accrual (ABSDA). Gambaran variabel penelitian dapat dilihat pada Tabel 2 , 3, dan 4 . 
Tabel 1. Sampel Penelitian

1. Perusahaan publik yang tidak teregulasi 223 terdaftar di BEI tahun 2010-2011

2. Perusahaan publik yang tidak teregulasi yang tidak menerbitkan laporan tahunan pada tahun 2010-2011

3. Perusahaan publik yang tidak teregulasi yang menyajikan laporan keuangan dalam satuan mata uang asing pada tahun 20102011

4. Data tidak lengkap

Sampel yang digunakan

Tahun Pengamatan 2

Jumlah sampel total selama periode penelitian

Tabel 2. Deskriptif Variabel Penelitian

\begin{tabular}{ccrrr}
\hline & $\mathrm{N}$ & Minimum & Maximum & \multicolumn{1}{c}{ Mean } \\
\hline LnSize & 348 & 23,0529 & 31,4692 & 27,5621 \\
Lev & 348 & 0,0058 & 2,0691 & 0,4818 \\
OCF & 348 & $-0,2939$ & 0,4235 & 0,0508 \\
GWTH & 348 & $-4,8441$ & 11,4053 & 1,6550 \\
ABSDA & 348 & 0,00046 & 0,68963 & 0,08942 \\
\hline
\end{tabular}

Tabel 3. Hasil Distribusi Frekuensi Ukuran KAP

\begin{tabular}{lcc}
\hline & $\begin{array}{c}\text { Jumlah } \\
\text { Perusahaan }\end{array}$ & Persentase \\
\hline Auditor KAP Non Big- 4 & 238 & $68 \%$ \\
Auditor KAP Big- 4 & 110 & $32 \%$ \\
\hline Total & 348 & $100 \%$ \\
\hline
\end{tabular}

Tabel 4. Hasil Distribusi Frekuensi Spesialisasi industri auditor

\begin{tabular}{lcc}
\hline & $\begin{array}{c}\text { Jumlah } \\
\text { Perusahaan }\end{array}$ & Persentase \\
\hline Auditor Non Spesialis & 254 & $73 \%$ \\
Auditor Spesialis & 94 & $27 \%$ \\
Total & 348 & $100 \%$ \\
\hline
\end{tabular}

Berdasarkan Tabel 3 dapat dilihat terdapat 110 perusahaan atau $32 \%$ perusahaan yang menggunakan jasa KAP Big-4 dalam mengaudit laporan keuangannya. Tabel 4 menjelaskan terdapat 94 perusahaan atau 27\% perusahaan yang menggunakan jasa spesialisasi industri auditor dalam mengaudit laporan keuangannya.

\section{Uji Asumsi Klasik}

Sebelum melakukan analisis regresi, diperlukan pengujian asumsi klasik agar sampel dapat benar-benar mewakili populasi secara keseluruhan. Uji asumsi klasik yang dilakukan dalam penelitian ini meliputi uji normalitas, uji multikolineritas, uji autokorelasi dan uji heteroskedastisitas.

Hasil uji normalitas dengan menggunakan uji statistik non-parametrik Kolmogorov-Smirnov (KS) yang menunjukkan nilai Kolmogorov-Smirnov sebesar 3,196 dan tidak signifikan jika nilai $\mathrm{p}$ (asymp.sig. 2-tailed) $<0,05$. Karena nilai $\mathrm{p}$ (asymp.sig 2-tailed) sebesar 0,000 ( $\mathrm{p}<0,05)$ maka menunjukkan bahwa residual tidak terdistribusi secara normal. Untuk menormalkan data residual tersebut, dilakukan transformasi data dengan metode logaritma natural (Ln) (Ghozali 2011). Metode logaritma natural yang dilakukan adalah dalam bentuk semi-log. Sehingga model regresi berubah menjadi:

\section{LnABSDA = $\alpha+81$ BIG-4+ 62 SPEC+ 63 SIZE+ 84 $\mathrm{LEV}+85 \mathrm{OCF}+86 \mathrm{GWTH}+\varepsilon$}

Hasil uji multikolinieritas menunjukkan bahwa nilai tolerance berada diantara nilai 0,441 hingga 0,943 dan nilai VIF berada diantara nilai 1,060 hingga 2,268. Berdasarkan hasil pengujian tersebut, tidak ada satupun variabel bebas (variabel independen) yang memiliki nilai tolerance dibawah 0,10 dan nilai VIF diatas 10. Sehingga dapat disimpulkan bahwa tidak terjadi multikolinieritas antar variabel bebas di dalam model regresi.

Hasil uji autokorelasi dari pengujian statistik menggunakan uji Run Test. Uji Run Test digunakan untuk melihat apakah data residual terjadi secara random atau tidak (Ghozali 2011). Uji Run Test menunjukkan nilai signifikansi sebesar 0,390 lebih dari 0,05 maka dapat disimpulkan bahwa dalam model regresi tidak terdapat masalah autokorelasi.

Hasil uji heteroskedastisitas dengan menggunakan uji Glejser yang menunjukkan bahwa nilai signifikansinya berada di antara 0,052 hingga 0,785. Berdasarkan hasil pengujian tersebut, tidak ada variabel yang memiliki nilai di bawah 0,05. Sehingga dapat disimpulkan bahwa tidak terdapat heteroskedastisitas pada data yang diuji dalam model regresi.

\section{Pengujian Hipotesis}

Hasil pengujian hipotesis dapat dilihat pada Tabel 5.

Tabel 5. Pengujian Hipotesis

\begin{tabular}{lccc}
\hline Variabel & $\begin{array}{c}\text { Unstandarized } \\
\text { Coefficients (B) }\end{array}$ & $\mathrm{t}$ & Sig \\
\hline (Constant) & $-1,820$ & $-1,551$ & 0,122 \\
Big- 4 & 0,240 & 1,185 & 0,237 \\
Spec & $-0,602$ & $-3,038$ & 0,003 \\
LnSize & $-0,051$ & $-1,190$ & 0,235 \\
Lev & 0,463 & 1,939 & 0,053 \\
OCF & $-1,907$ & $-3,004$ & 0,003 \\
GWTH & 0,099 & 2,675 & 0,008 \\
\hline Adjusted $\mathrm{R}^{2}=0,072 ;$ F-test $=5,500 ;$ Sig $\mathrm{F}=0,000$ \\
\hline
\end{tabular}


Berdasarkan hasil Tabel 5 dapat dilihat bahwa nilai dari adjusted $R^{2}$ sebesar 0,072 yang berarti sebesar $7,2 \%$ variasi variabel terikat dapat dijelaskan oleh variasi dari variabel bebas. Oleh karena itu, dapat disimpulkan bahwa sebesar $7,2 \%$ manajemen laba yang diproksikan dengan nilai absolute discretionary accruals dipengaruhi secara bersama-sama oleh variabel independen ukuran KAP (BIG-4) dan spesialisasi industri auditor (SPEC) dan variabel kontrol ukuran perusahaan (SIZE), leverage (LEV), rasio arus kas operasi (OCF), dan pertumbuhan perusahaan (GWTH). Sedangkan sisanya 92,8\% dipengaruhi oleh variabel lain yang tidak dimasukkan didalam model. Meskipun nilai adjusted $\mathrm{R}^{2}$ rendah, tetapi dengan nilai F-test sebesar 5,500 dengan signifikansi 0,000, bahwa angka signifikansi 0,000 lebih kecil dari 0,05 mengindikasikan bahwa model yang digunakan dalam penelitian ini layak.

\section{Ukuran KAP dan Manajemen Laba}

Dari Tabel 5 menunjukkan variabel ukuran KAP memiliki t-hitung sebesar 1,185 dan nilai signifikansi sebesar 0,237. Jika melihat tingkat signifikansinya berada di atas 0,05 maka ukuran KAP tidak berpengaruh signifikan terhadap manajemen laba. Hal ini berarti bahwa hipotesis 1 ditolak. Hasil pengujian hipotesis pertama ini tidak sejalan dengan penelitian yang dilakukan oleh Gerayli et al. (2011) dan Rusmin (2010) yang menemukan ukuran KAP berpengaruh negatif terhadap manajemen laba. Akan tetapi, hasil pengujian dari hipotesis yang pertama ini sejalan dengan penelitian dari Luhgiatno (2010) dan Rahmadika (2011) yang menyatakan bahwa KAP Big- 4 ternyata belum mampu membatasi praktik manajemen laba.

Kualitas audit yang diproksikan dengan ukuran KAP, dalam penelitian ini tidak berpengaruh terhadap manajemen laba. Hal ini dimungkinkan praktik manajemen laba terjadi karena perusahaan memiliki keinginan agar kinerja keuangan perusahaan tampak bagus dimata calon investor, namun mengabaikan keberadaan auditor Big-4 (Luhgiatno 2010). Selain itu, dengan adanya keberadaan auditor Big4 bukan untuk mengurangi manajemen laba, tetapi lebih kepada peningkatan kredibilitas laporan keuangan dengan mengurangi gangguan yang ada didalamnya sehingga bisa menghasilkan laporan keuangan yang lebih handal (Cahyonowati 2006).

\section{Spesialisasi Industri Auditor dan Manajemen Laba}

Dari hasil pengujian hipotesis yang kedua menunjukkan variabel spesialisasi industri auditor
(SPEC) memiliki t-hitung sebesar -3,038 dan nilai signifikansi sebesar 0,003. Jika memperhatikan tingkat signifikansinya berada di bawah 0,05 maka spesialisasi industri auditor berpengaruh negatif terhadap manajemen laba. Hal ini berarti bahwa hipotesis 2 diterima. Hasil pengujian hipotesis kedua ini sejalan dengan penelitian yang dilakukan oleh Balsam et al. (2003) dan Gerayli et al. (2011) yang menunjukkan bahwa spesialisasi industri auditor berpengaruh negatif dengan manajemen laba. Hasil penelitian ini juga konsisten dengan penelitian dilakukan Gramling et al. (2001) menunjukkan bahwa penggunaan spesialisasi industri auditor dapat mengetahui adanya manajemen laba, kesalahan prediksi dan kemampuan untuk memprediksi arus kas mendatang. Becker et al. (1998) menjelaskan bahwa spesialisasi industri auditor dapat mendeteksi manajemen laba karena spesialisasi industri auditor memiliki pengetahuan lebih (superior knowledge) tentang industri tertentu. Kemampuan spesialisasi industri auditor untuk mendeteksi manajemen laba akan mendorong klien untuk tidak melakukan manajemen laba sehingga kualitas laba meningkat. Selain itu spesialisasi industri auditor juga dapat mendeteksi manajemen laba untuk mempertahankan reputasi mereka sebagai auditor.

Hasil penelitian ini sejalan dengan penelitian Maletta dan Wright (1996) yang menyimpulkan bahwa auditor yang memiliki pemahaman yang lebih komprehensif tentang suatu tren dan karakteristik industri tertentu akan lebih efektif dalam melakukan audit daripada auditor yang tidak memiliki pengetahuan tentang industri tertentu tersebut. Dengan demikian, spesialisasi industri auditor memiliki pemahaman yang lebih baik tentang karakteristik industri, lebih patuh terhadap standar auditing, memahami resiko dan masalah dalam industri yang diaudit, memiliki kemampuan mendeteksi error lebih baik daripada non spesialisasi industri auditor sehingga spesialisasi industri auditor dapat lebih baik mengurangi manajemen laba akrual daripada non spesialisasi industri auditor (Januarsi 2009).

\section{Pengaruh ukuran perusahaan, leverage, rasio arus kas operasi dan pertumbuhan perusahaan terhadap manajemen laba.}

Variabel kontrol ukuran perusahaan memiliki t-hitung sebesar -1,190 dengan tingkat signifikansi 0,235. Tingkat signifikansi berada diatas 0.05. Hal tersebut memberi arti bahwa ukuran perusahaan tidak berpengaruh terhadap manajemen laba. Zuhroh (1997) menyatakan bahwa besar kecilnya asset yang dimiliki oleh perusahaan 
tidak menjadi pertimbangan satu-satunya bagi para investor dalam mengambil pertimbangan investasi, tetapi masih terdapat faktor-faktor lain yang lebih penting, misalnya tingkat keuntungan dan prospek perusahaan di masa yang akan datang, dan besarnya asset yang dimiliki oleh perusahaan tidak menjamin menghasilkan kinerja yang baik.

Variabel kontrol leverage memiliki t-hitung sebesar 1,939 dan nilai signifikansi sebesar 0,053. Nilai signifikansi sebesar $0,053>0,05$ berarti variabel leverage tidak signifikan pada level $5 \%$ sehingga dapat disimpulkan bahwa leverage tidak berpengaruh terhadap manajemen laba. Hal ini dikarenakan perusahaan tidak harus bergantung pada manajemen laba untuk keamanan perjanjian hutang. Zhou dan Elder (2004) menyatakan ada beberapa hal lain yang berpengaruh pada keamanan perjanjian hutang, misalkan kredibilitas perusahaan, jaminan yang diberikan perusahaan dan ketepatan waktu pembayaran angsuran.

Variabel kontrol rasio arus kas operasi memiliki t-hitung sebesar -3,004 dan nilai signifikansi sebesar 0,003. Nilai signifikansi sebesar $0,003<0,05$ berarti variabel rasio arus kas operasi signifikan pada level $5 \%$ sehingga dapat disimpulkan bahwa rasio arus kas operasi berpengaruh negatif terhadap manajemen laba. Hal ini sesuai dengan hasil penelitian Chen et al. (2005). Arus kas dari aktivitas operasi mencerminkan kemampuan riil perusahaan dalam menghasilkan dana (arus dana). Artinya, jika arus kas dari aktivitas operasi perusahaan tinggi, motivasi untuk melakukan manajemen laba akan menurun karena perusahaan secara riil mampu menghasilkan dana yang cukup sehingga tidak perlu melakukan manajemen laba. Hal yang sebaliknya terjadi pada saat arus kas dari aktivitas operasi rendah, dimana manajemen akan termotivasi untuk menunjukkan perbaikan kinerja dengan melakukan manajemen laba (Nastiti dan Gumanti 2011).

Variabel kontrol pertumbuhan perusahaan memiliki t-hitung sebesar 2,675 dan nilai signifikan sebesar 0,008. Nilai signifikansi sebesar 0,008 $<0,05$ berarti variabel pertumbuhan perusahaan signifikan pada level 5\% sehingga dapat disimpulkan bahwa pertumbuhan perusahaan berpengaruh positif terhadap manajemen laba. Madhogarhia \& Koher (2009) menemukan bahwa perusahaan dengan tingkat pertumbuhan yang semakin tinggi akan cenderung lebih banyak melakukan manajemen laba. Hal ini dapat disebabkan perusahaan dengan pertumbuhan yang tinggi mempunyai insentif untuk mempertahankan tingkat partumbuhannya yang tinggi dengan melakukan manajemen laba.

\section{KESIMPULAN DAN SARAN}

Berdasarkan data yang telah dikumpulkan dan pengujian yang telah dilakukan terhadap permasalahan dengan menggunakan model analisis regresi berganda, maka dapat diambil kesimpulan kualitas audit yang diproksikan dengan ukuran KAP (KAP The big- 4 dan KAP non The big-4) tidak berpengaruh terhadap manajemen laba. Hasil mendukung penelitian Luhgiatno (2010) dan Rahmadika (2011). Hal ini dimungkinkan praktik manajemen laba terjadi karena perusahaan memiliki keinginan agar kinerja keuangan perusahaan tampak bagus dimata calon investor, namun mengabaikan keberadaan auditor Big4 (Luhgiatno 2010).

Kualitas audit yang diproksikan dengan spesialisasi industri auditor berpengaruh negatif terhadap manajemen laba. Hasil tersebut mendukung penelitian Gerayli et al. (2011), Becker et al. (1998) dan Gramling et al. (2001). Hal ini dikarenakan spesialisasi industri auditor memiliki pengetahuan lebih (superior knowledge) tentang industri tertentu. Kemampuan spesialisasi industri auditor untuk mendeteksi manajemen laba akan mendorong klien untuk tidak melakukan manajemen laba sehingga kualitas laba meningkat. Selain itu spesialisasi industri auditor juga dapat mendeteksi manajemen laba untuk mempertahankan reputasi mereka sebagai auditor.

Penelitian ini menggunakan variabel kontrol berupa ukuran perusahaan, leverage, rasio arus kas operasi dan pertumbuhan perusahaan. Ukuran perusahaan tidak berpengaruh terhadap manajemen laba. Hasil tersebut tidak mendukung penelitian Gerayli et al. (2011). Hal ini dimungkinkan karena besar kecilnya asset yang dimiliki oleh perusahaan tidak menjadi pertimbangan satusatunya bagi para investor dalam mengambil pertimbangan investasi (Zuhroh 1997). Variabel leverage tidak berpengaruh terhadap manajemen laba. Hasil tersebut tidak mendukung penelitian Gerayli et al. (2011). Hal ini dimungkinkan perusahaan tidak harus bergantung pada manajemen laba untuk keamanan perjanjian hutang. Variabel rasio arus kas operasi berpengaruh negatif terhadap manajemen laba. Hasil tersebut tidak mendukung penelitian Gerayli et al. (2011). Ketika arus kas dari aktivitas operasi perusahaan tinggi, motivasi untuk melakukan manajemen laba akan menurun karena perusahaan secara riil mampu menghasilkan dana yang cukup sehingga tidak perlu melakukan manajemen laba. Variabel pertumbuhan perusahaan berpengaruh positif terhadap manajemen laba. Hasil tersebut mendukung penelitian Gerayli et al. (2011). Perusahaan dengan pertumbuhan yang tinggi mempunyai 
insentif untuk mempertahankan tingkat partumbuhannya dengan melakukan manajemen laba.

Keterbatasan dari penelitian ini antara lain pengukuran terhadap variabel manajemen laba hanya berfokus terhadap manajemen laba akrual saja. Untuk penelitian mendatang hendaknya mempertimbangkan unsur manajemen laba riil (A'Rahman dan Hutagaol 2008; Lestari dan Herusetya 2013). Selain itu pengukuran kualitas audit pada penelitian ini hanya menggunakan ukuran KAP dan spesialisasi industri auditor. Pada penelitian berikutnya dapat menggunakan masa penugasan audit dan independensi sebagai ukuran kualitas audit (DeAngelo 1981 dan Lestari dan Herusetya 2013).

Berdasarkan hasil penelitian ini, dapat disarankan bagi investor sebelum melakukan pengambilan keputusan investasi di suatu perusahaan untuk hendaknya lebih memilih perusahaan yang menggunakan spesialisasi industri auditor karena dengan adanya spesialisasi industri auditor dapat membatasi praktik manajemen laba yang terjadi di suatu perusahaan.

\section{DAFTAR PUSTAKA}

Andreas, Hans Hananto. (2012), "Spesialisasi Industri Auditor Sebagai Prediktor Earnings Response Coefficient Perusahaan Publik Yang Terdaftar Di BEF”, Jurnal Akuntansi dan Keuangan, Vol. 14, No. 2, November 2012: 6980.

Anthony, Robert, N., \& Govindarajan, V. (2005), "Sistem Pengendalian Manajemen", Jakarta: Salemba Empat.

A'Rahman, A., \& Hutagaol, Y. (2008). "Manajemen Laba Melalui Akrual dan Aktivitas Real Pada penawaran Perdana dan Hubungannya dengan Kinerja Jangka Panjang." Jurnal Akuntansi dan Keuangan Indonesia, Vol. 5, No. 1, Juni 2008.

Balsam, S., Khrisnan, J., dan Yang, J. S. (2003), "Auditor Industry Specialization and Earnings Quality”. Auditing: A journal of Practice \& Theory, 22. p. 71.

Becker, C.L., Mark, L. DeFond, J.J. \& Subramanyam, K.R. (1998), "The Effect of Audit Quality on Earnings Management". Social Science Research Network, 1-24

Cahyonowati, Nur (2006), The Effect of Firm Size, Leverage and Firm Growth on Earnings Management with Auditor's Industry Expertise as a Moderating Variable (Empirical Evidence from the Jakarta Stock Exchange. Tesis tidak dipublikasikan. Magister Akuntansi Undip.
Chen, K., Lin, K., \& Zhou, J. (2005), “Audit Quality and Earnings Management for Taiwan IPO firms. Managerial Auditing Journal, 20(1), 86-104.

Craswell, A. T., Francis, J. R., \& Taylor, S. L. (1995), "Auditor brand name reputations and industry specialisations", Journal of Accounting and Economics, 20(3), 297-322. http://dx. doi.org/10.1016/0165-4101(95)00403-3

DeAngelo, Linda Elizabeth. (1981), "Auditor Size And Audit Quality," Journal of Accounting and Economics, 3(3). 1981, pp. 183-199.

DeAngelo. (1986). "Accounting Numbers as Market Valuation Substitutes: A Study of Management Buyouts of Public Shareholders." Thev Accounting Review, 61, 400-420

Dunn, K., Mayhew, B., and Morsfield, S. (2000), "Auditor Industry Specialization and Client Disclosure Quality", http://www.papers.ssrn. com/diakses 18 Januari 2015.

Ebrahim, Ahmad, (2001). "Audit Quality, Auditor Tenure, Client Importance, and Earnings Management: An Additional Evidence". http:// www.papers.ssrn.com/diakses 18 Januari 2015.

Gramling, A.A., Johnson, V.E. \& Khurana, I.K. (2001), "Audit Firm Industry Specialization and Financial Reporting Quality, "Working Paper, Georgia State University and University of Missouri-Columbia.

Gerayli, M., Ma'atofa, S., \& Yane Sari, A.M. (2011). "Impact of audit quality on Earnings Management: From Iran”. International Research Journal of Finance and Economics, Issue 66, pp. 77-84. www.eurojournals.com/IRJFE_66

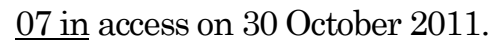

Ghozali, Imam. (2011). "Aplikasi Analisis Multivariate dengan Program IBM SPSS 19”, Semarang: Badan Penerbit Universitas Diponegoro.

Healy, P. M. (1985) "The effect of bonus schemes on accounting decisions," Journal of Accounting and Economics, 7(1-3), 1985, 85-107.

Healy, P.M and Palepu K.G. (2001), "Information Asymetri, Corporate Disclosure and The Capital Markets: A Review of The Empirical Disclosure Literature", Journal of Accounting and Economics, 31(1-3), 405-440.

Herusetya, A. (2009), "Efektifitas Pelaksanaan Corporate Governance dan Audit EksternalAuditor Dengan Spesialisasi Industri Dalam Menghambat Manajemen Laba”, Jurnal Akuntansi dan Auditing Indonesia, 13(2), 167-188.

Indah, E., dan Erni, E. (2006). "Manajemen Laba Pada Perioda Sebelum dan Sesudah Penawaran Saham Perdana di Bursa Efek Jakarta: dengan Model DeAngelo", Jurnal Riset Akuntansi dan Keuangan, 2(2), 67-81. 
Januarsi, Yeni. (2009). "Peran Auditor Spesialis Dalam Mengurangi Manajemen Laba Akrual Dan Manajemen Laba Real Pada Periode Sebelum dan Sesudah Keputusan Menteri Keuangan No. 423/KMK.06/2002", Simposium Nasional Akuntansi 12, Palembang: 4-6 November 2009.

Kompas. (2002). "Kasus Kimia Farma Kesalahan Manajemen Lama". Kompas, 21 November 2002.

Krishnan, Gopal, V. (2003). "Does Big- Six Auditor Industry Expertise Constrain Earnings Management?" Accounting Horizon, 17, 1.

Lestari, P., dan Herusetya, A. (2013). Pengaruh Kualitas Audit Terhadap Manajemen Laba Transaksi Real-Pengakuan Pendapatan Strategis. Jurnal Akuntansi dan Keuangan, Vol. 15. No 2, November 2013, 75-85.

Leuz, C., Nanda, D., \& Wysocki, P. (March 2003). "Earnings management and investor protecttion: an international comparison". Journal of Financial Economics. 69. www. elsevier.com. diunduh pada 20 Januari 2015.

Luhgiatno. (2010). "Analisis Pengaruh Kualitas Audit Terhadap Manajemen Laba (Studi Pada Perusahaan Yang Melakukan IPO di Indonesia)", Fokus Ekonomi, Vol. 5, No. 2.

Madhogarhia, P., \& Kohers, S. N. (2009). Earnings Management Practices Among Growth and Value Firms. Applied Financial Economics, 19, 1767-1778.

Mayangsari, Sekar. (Mei 2004). "Bukti Empiris Pengaruh Spesialisasi Industri Auditor Terhadap Earnings Response Coefficient", Jurnal Riset Akuntansi Indonesia, 7(2), pp.154-178.

Maletta, M., and Wright, A. (1996), "Audit evidence planning: an examination of industry error characteristics." Auditing: A Journal of Practice and Theory. 15(Spring), 71-86.

Meutia, Inten. (2004), "Pengaruh Independensi Auditor Terhadap Manajemen Laba untuk KAP Big-5 dan Non Big-5”. Jurnal Riset Akuntansi Indonesia. 7(3), 333-350.

Nastiti, A. S., dan Gumanti, T. A. (2011), "Kualitas Audit dan Manajemen Laba Pada Initial Public Offerings di Indonesia”, Simposium Nasional Akuntansi XIV, Banda Aceh: 21-22 Juli 2011.
Rahmadika. (2011), "Pengaruh kualitas Auditor terhadap Manajemen Laba (Studi Epiris pada Perusahaan Manufaktur yang terdaftar di Bursa Efek Indonesia Tahun 2008-2009)", Skripsi Universitas Diponegoro.

Ratmono, Dwi (2010), "Manajemen Laba Riil dan Berbasis Akrual: Dapatkah Auditor yang Berkualitas Mendeteksinya?”. Simposium Nasional Akuntansi 13. Purwokerto.

Rusmin (2010), "Auditor Quality and Earnings Management: Singaporean Evidence", Managerial Auditing Journal, 25(7), 618-638.

Sanjaya, I Putu Sugiartha. (2008), "Auditor Eksternal, Komite Audit, dan Manajemen Laba”, Jurnal Riset Akuntansi Indonesia. 11(1), 97-116.

Setiawati, L., \& Na’im, A. (May 2001), "Bank Health Evaluation by Bank Indonesia and Earnings Management in Banking Industry", Gadjah Mada International Journal of Business. 3(2), 159-176.

Subramanyam, K. R. (1996), "The Pricing of Discretionary Accruals". Journal of Accounting and Economics. 22, 249-281.

Watts, R. L., and Zimmerman, J. L. (January 1990), "Positive Accounting Theory: A Ten Year Perspective," The Accounting Review. 65(1), 131-158.

Widhiarso, Wahyu. (2011). "Analisis Data Penelitian Dengan Variabel Kontrol', Tersedia dari: URL: http:/widhiarso.staff.ugm.ac.id/files/Analisis Data dengan Menggunakan Variabel Kontrol.pdf diakses 16 Juli 2013.

Teoh, S. H., Welch, I., dan Wong, T. J. (1998), "Earnings management and the long-run market performance of initial public offerings," The Journal of Finance. 50, 63-99.

Zhou, J., and Elder, R. (2001). "Audit Firm Size, Industry Specialization and Earnings Management by Initial Public Offering Firms" SUNY at Binghamton working paper.

Zhou, J., and Elder, R. (2004). "Audit Quality and Earnings Management by Seasoned Equity Offering Firms", Asia-Pacific Journal of Accounting and Economics. 11(2), 95-120.

Zuhroh, Diana. (1997). "Faktor-Faktor yang Berpengaruh pada Tindakan Perataan Laba pada Perusahaan Go-Publik di Indonesia”. Simposium Nasional Akuntansi I. Yogyakarta: September. 